Vladimir Nedić ${ }^{1}$

Slobodan Cvetanović ${ }^{2}$

Danijela Despotović ${ }^{3}$
JEL: 030, 011

DOI: 10.5937/industrija42-6313

UDC: $330.341 .1(497-15)$

005.94:330.47

Original Scientific Paper

\title{
ICT as a Component of Knowledge Economy Development of Western Balkan Countries
}

\author{
Article history: \\ Received: 18 June 2014 \\ Sent for revision: 9 August 2014 \\ Received in revised form: 21 October 2014 \\ Accepted: 13 November 2014 \\ Available online: 23 December 2014
}

\begin{abstract}
Based on the measurement of World Bank Institute's knowledge economy index (KAM), this paper researches the achieved level of ICT application in four Western Balkan countries (Albania, Bosnia and Herzegovina, Macedonia and Serbia) and six selected EU neighbouring countries (Austria, Bulgaria, Greece, Croatia, Romania, Slovenia). Correlation analysis was used to research the interdependence of ICT and other KEI pillars, and GDP per capita at global level and in ten observed countries. Afterwards, depth of the gap of the ICT application level was identified by using the cluster and radar chart analyses among ten selected European countries placed into two groups (Western Balkan countries and their neighbouring countries). Finally, using the overtime comparison model of the most recent available data and data from year 2000, the trend of the change of key variables' values of ICT pillar in Western Balkan countries and neighbouring EU countries was additionally researched. The conclusion arises that the determined gap in ICT application between Western Balkan countries and selected EU countries means, per se, that these countries relatively lag behind in knowledge economy development, and, moreover, they lag behind in the development of information society in general.
\end{abstract}

Keywords: ICT, knowledge economy, Western Balkan countries, selected EU countries

\footnotetext{
${ }^{1}$ University of Kragujevac, Faculty of Phil. and Arts

${ }^{2}$ University of Kragujevac, Faculty of Economics

${ }^{3}$ University of Kragujevac, Faculty of Economics, ddespotovic@kg.ac.rs
} 
Nedić V. et al.: ICT as a Component of Knowledge Economy Development of ...

\section{IKT kao komponenta razvoja ekonomije znanja zemalja Zapadnog Balkana}

Apstrakt: $U$ radu se na osnovu metrike indeksa ekonomije znanja (KAM) Instituta Svetske Banke istražuje dostignuti nivo primene IKT u četiri zemlje Zapadnog Balkana (Albanija, Bosna i Hercegovina, Makedonija i Srbija) $i$ šest selektovanih zemalja EU (Austrija, Bugarska, Grčka, Hrvatska, Rumunija $i$ Slovenija) iz njihovog najbližeg okruženja. Korelacionom analizom ispitivana je međuzavisnost IKT stuba sa ostalim stubovima indeksa ekonomije znanja (KEI), kao $i$ visinom GDP per capita na globalnom nivou i na nivou deset posmatranih zemalja. Potom je korišćenjem klaster $i$ radar chart analize identifikovana dubina jaza između nivoa korišćenja ICT u deset izabranih zemalja Evrope svrstanih u dve grupe (zemlje Zapadnog Balkana i zemlje EU iz njihovog neposrednog okruženja). Na kraju je primenom modela over time komparacije najnovijih dostupnih podataka u odnosu na podatke iz 2000. godine dodatno ispitivan trend promena vrednosti ključnih varijabli IKT stuba zemalja Zapadnog Balkana i selektovanih zemalja EU. Zaključak je da ustanovljeno zaostajenje $u$ primeni IKT u zemljama Zapadnog Balkana $u$ odnosu na EU zemlje iz njihovog najbližeg okruženja per se znači relativno nazadovanje ovih zemalja u razvoju ekonomije znanja, $i$ šire, njihovo relativno kašnjenje u razvoju informatičkog društva u celini

Ključne reči: IKT, ekonomija znanja, zemlje Zapadnog Balkana, selektovane zemlje EU.

\section{Introduction}

Contemporary social-economic reality is formed under growing influence of ICT. It is often referred to as information society, while the economy system which develops under the conditions of information society is referred to as knowledge economy. (Brinkley, 2006) World economy finds itself at the crossroads between the development of so far dominant way of production based on mass use of resources, on one hand, and development of economy based on knowledge on the other hand. (Araya, 2010). Basically, these are development models which use the same factors, but in significantly different proportions. Thereat, the center moves in the direction of growing use of knowledge and innovation factors in the process of creation of material values in modern conditions. This is not only the case in developed economies which include most of the EU countries, but also in countries with underdeveloped economies which try to aim their economic activities in the direction of knowledge economy development. The latter includes, among great number of developing countries all around the world, countries of Western Balkan 
Nedić V. et al.: ICT as a Component of Knowledge Economy Development of ...

region (Albania, Bosnia and Herzegovina, Macedonia and Serbia ${ }^{4}$ ) which try to become EU members as soon as possible, while developing its knowledge economies. (Lojpur \& Peković, 2013)

It is important to mention that there is still no unique definition of knowledge economy, and what all the attempts of trying to make the term precise have in common, is intensive inclusion of ICT in all economy sections in order to increase productivity and to improve competitiveness of companies, branches and regions. (Negroponte, 1996) Knowledge economy is the term which is closely related to trends of globalization and information society development. In Global and Information Economics, knowledge is increasingly asserted as a factor which creates additional value and new knowledge at the same time. Hence, capital accessibility is no longer essential for the quality economy growth. The most important thing is possession of adequate information. Within this context, production is more and more based on the use of knowledge, new technology and innovations as the most significant sources of life standard improvement and creating new work places. (Škuflić \& Vlahinić-Dizdarević, 2003)

In knowledge economy, studying and knowledge creation in producing goods and providing service is of principle importance. Thereat, the fact that from the aspect of theory, knowledge economy's paradigm still is not, by far, unequivocally scientifically grounded, is of minor significance. Moreover, many people think that there are still no objective elements which prove its existence. (Drašković, Jovović \& Drašković, 2013) This is due to the fact that traditional categorical apparatus of science of economics is used for the interpretation of logics and the essence of contemporary economic activities. However, in the sense of pragmatics, knowledge economy objectively stands out as new social and economic environment which decreases the significance of categories such as national sovereignty, institutions for country's regulation, and also application of all known economic theories in explanation of its dimensions. (Drašković, Jovović \& Drašković, 2013)

Starting from already explained observations related to the development of knowledge economy and objective significance of ICT complex in its generating, we define the aim of this paper as an attempt to determine the level of ICT application in the Western Balkan countries and selected EU countries from their immediate surroundings (Austria, Bulgaria, Greece, Croatia, Romania and Slovenia) based on the measurement of knowledge economy index of World Bank Institute. Bearing in mind the fact that growing application of ICT represents one of the main drivers of the economic growth

\footnotetext{
${ }^{4}$ Croatia is officially an EU member since $1 / 07 / 2013$. Montenegro has been omitted from the research due to incomplete data in KAM database. Kosovo is still not recognized by the United Nations Organization.
} 
Nedić V. et al.: ICT as a Component of Knowledge Economy Development of ...

(Colecchia \& Schreyer, 2002) and that knowledge economy's development demands the environment which enforces ICT diffusion in basically every area of the economy, hypotheses defined within this research are:

- H1: Higher level of ICT application (represented in ICT pillar of KEI) means better economy performance (represented by GDP per capita).

- H2: There is a significant lagging of the Western Balkan countries in reached ICT application level in relation to selected EU countries, which are thought to be the least developed and innovative countries of EU (Despotovic, Cvetanović \& Nedić, 2014).

$\mathrm{H} 1$ hypothesis was examined on the global level, by using correlation and regression analyses, while $\mathrm{H} 2$ hypothesis was examined by the comparison of ICT pillars of Western Balkan countries and six selected EU countries by using cluster and radar chart analyses based on the World Bank's most recent available data for the knowledge economy assessment.

After the examination of the hypotheses, trend of changes of reached ICT application level within all observed countries was additionally examined. Trend of changes was shown through over time diagrams of comparison.

While defining the aim of the research, and two starting hypotheses, we were completely aware of the fact that the question of adequacy of general evaluations based only on World Bank's composite indexes $\mathrm{KEI}$ and $\mathrm{KI}$ can rightfully be asked. By that fact alone, the doubt of their unequivocal consistency and validity arises. Mentioned question is of particular significance for the countries in the transition, because for some of them, these indicators were not calculated at all. However, we believe that, even though there are possible critical observations of the use of composite indices for expression of complex economic categories, there is also justification for their use, especially during conducting comparative analysis, as it was the case in this paper. Even more so because, data about knowledge economy pillar's indicators are used in this research, and they are based on the exact facts.

\section{Literature Overview}

In recent years, economic theories related to knowledge economy are the subject of intensive research. Knowledge has become main driving force of economic and social development worldwide. Followed by globalization and accelerated by the rapid distribution and transfer of knowledge and helped by ICT, this development affects all countries and regions, public institutions, corporative world and life of people. The results of numerous researches show that use of ICT has a stimulating effect on the growth and innovation of 
Nedić V. et al.: ICT as a Component of Knowledge Economy Development of ...

economy, improvement of country's competitiveness, and decrease of harmful emissions. (Ollo-López \& Aramendía-Muneta, 2012). A number of researches is dedicated to consideration of the significance of ICT implementation in the growth of efficiency of small and medium-sized enterprises (Rai \& Lal, 2000)

Numerous studies show that world's economy is found in the midst of deep transformations, stimulated by globalization and supported by strong development of ICT, which accelerate transfer and use of information and knowledge. This powerful combination of forces alters people's lifestyle and redefines principles of company's operation in certain production sectors. (Carayannis et al. 2006)

Economists that support the knowledge economy concept believe that ICT sector has unquestionable significance in the economic growth. However, the quantification of the relationship greatly differs, depending on the author or country. Studies showed that less investment in ICT means slower progress towards knowledge economy and lower rate of technological changes in economy, as well as in society as a whole. (Atkinson, 2007)

Knowledge economy is formed and expanded due to the knowledge resource as a unique, unlimited, independent factor of production which cannot be replaced by other factors. This very knowledge transforms into economic goods and income in most of sections of economy, not only in those which are directly linked to the development of new technologies. (Atkinson \& Gottlieb, 2001) In knowledge economy, innovations are no longer reserved for new products and technologies. They are more and more characteristic of new forms, organization methods and forms of production management. (Drašković, 2010)

Economists point out that current changes in production are moving from production of material goods to production of non-material and information goods. (Shapiro \& Varian, 2013). Furthermore, they point out the fact that research and technological production sectors have the key influence on the growth of average labor productivity (Brynjolfsson \& Hit, 1996). Effective ICT use requires well-trained work force. Organizational change is the key which enables functioning of ICT within a company. ICT effects are related to level of competitiveness and willingness to experiment and be innovative and they appear with certain time delay. (Pilat, 2005) On macro plan, economic influence of ICT is reflected in a) stimulating development of innovations, b) competitiveness improvement, and c) realization of sustainable development concept (Selhofer et al, 2010) (Fig. 1.) 
Nedić V. et al.: ICT as a Component of Knowledge Economy Development of ...

Figure 1. ICT impacts in three domains

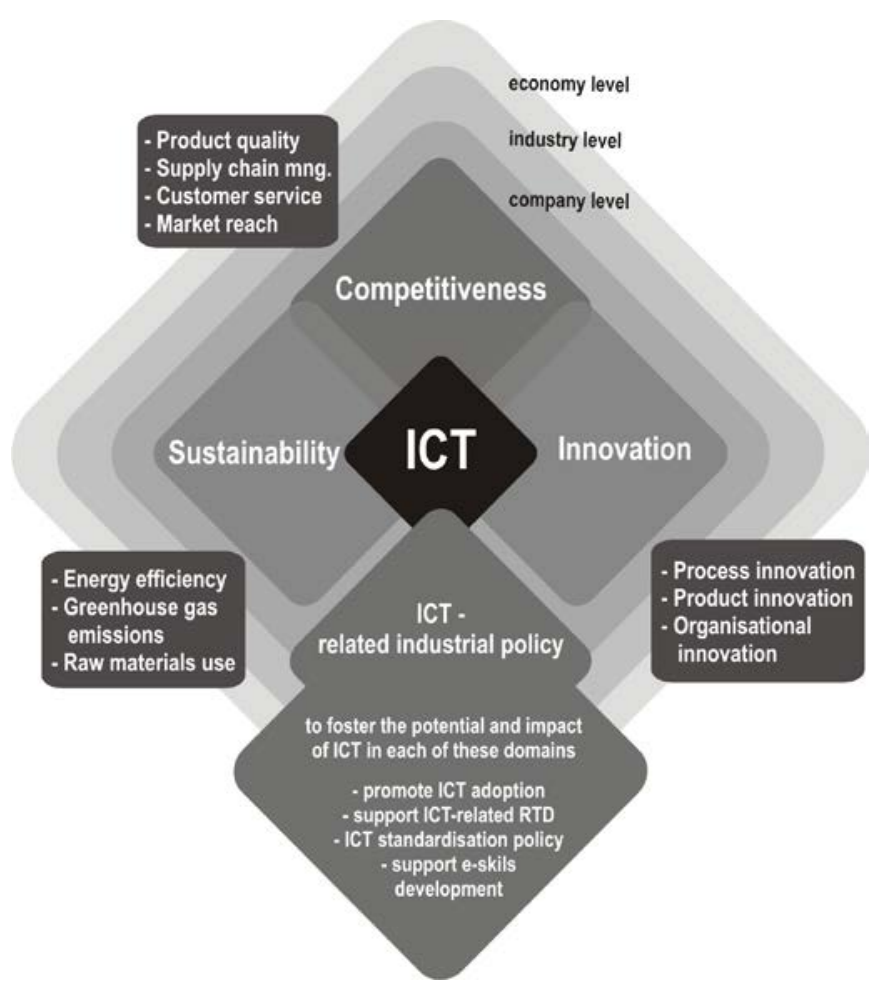

Authors' design modified according to:( Selhofer et al, 2010, p. 15)

The power of knowledge economy is grounded on cooperation between public and private sectors, the capacity of educational and scientific systems of a country, higher education, and development of ICT sector. Relying on ICT provides new work arrangements (working at home, part-time jobs, flexible hours), increased knowledge codification, and decrease of knowledge dissemination costs. (Trewin, 2002)

ICT undoubtedly represents one of the key generators of knowledge economy (Landefeld, 2001). Apart from that, these technologies are the main material resource in accomplishing contemporary way of life. They are widely used at work, in everyday life, culture, entertainment, and free time. There is almost no aspect of man's activity in which their influence cannot be felt. ICT sector development, especially the Internet, revolutionary changes technique of international trade of new, as well as traditional products and services. Networked ICT dramatically increases the quantity and value of information 
Nedić V. et al.: ICT as a Component of Knowledge Economy Development of ...

available to individuals, companies and governments enabling them in this way to have a more superior performance. (Mann \& Rosen, 2002)

ICT is differently developed in the world and its presence in the companies based on ICT is not coherent. It, per se, does not perform transformations in the society. It is best to refer to it as generator of knowledge creation in innovative societies, that is, to treat it as infrastructural component of knowledge economy development. (OECD, 1996) By transforming the world, it has provided environment for the increase of innovation and productivity in order to connect people more efficiently to create the new possibilities that improve the living standard of all the people worldwide. These technologies have changed the life of individuals, introducing them to new information society thus proving that they are key prerequisites of knowledge economy growth.

ICT is the tool for releasing creative potential and knowledge in people. However ICT sector has powerful effect as a production multiplier. For example, research from 1995 about the effect of software producer Microsoft on local economy found that each work place in Microsoft creates 6,7 new work places in the state of Washington, while each work place in plane factory Boeing creates 3,8 new work places (Mandel, 1997). Therefore, it is more and more evident that generating economic values is becoming more and more related to the willingness of certain countries to create added value through ICT services and products.

If we observe the papers which analyze this issue within Western Balkan's local setting, we can notice that the findings partially match our expectation. In the paper Krstić \& Džunić, 2013, values of some indicators of KEI pillars for Western Balkan countries and average of EU 27 were compared. The authors' conclusion is that 'values of ICT index measured in Western Balkan countries show their obvious lagging in relation to EU countries, except Croatia, which follows European average for most of the indicators. Of course, for any of analyzed Western Balkan countries, results of the first ten countries on KEI list, or the most developed European countries are inapproachable.' (Krstić \& Džunić, 2013, p-156).

\section{Research methodology}

In order to facilitate the creation of knowledge-based society, World Bank developed KAM whose aim is to enable basic assessment of country's willingness to develop knowledge-based economy and identify the fields in which creators of economic policy should increase investments. This is an interactive tool which enables comparison of countries according to the degree of knowledge based economy development. In KAM approach 
Nedić V. et al.: ICT as a Component of Knowledge Economy Development of ...

knowledge is measured based on 148 structural and qualitative indicators. The research included 146 countries, 90 of which are considered as developing economies. In order to enable flexible comparison of developing countries, that is certain segments of knowledge economy, each variable is available in absolute and relative value (normalized scale, from 0 to 10 in relation to other countries from comparison group). Comparison can be performed between certain countries (all 146) in relation to one of the countries of the seven regions (Northern America, Eastern Asia and Pacific, Southern Asia, Europe and Central Asia, Latin America and the Caribbean, Middle East and Northern Africa and Sub-Sahara Africa) or in relation to the region as a whole. Comparison can also be performed between the grouped countries according to GDP per capita. It can also be performed according to certain fields as well as individual indicators, which altogether enable the overview of different aspects of country's ability to create, disseminate and apply the knowledge in economy development.

Figure 2. Relationship of KAM indexes and indicators

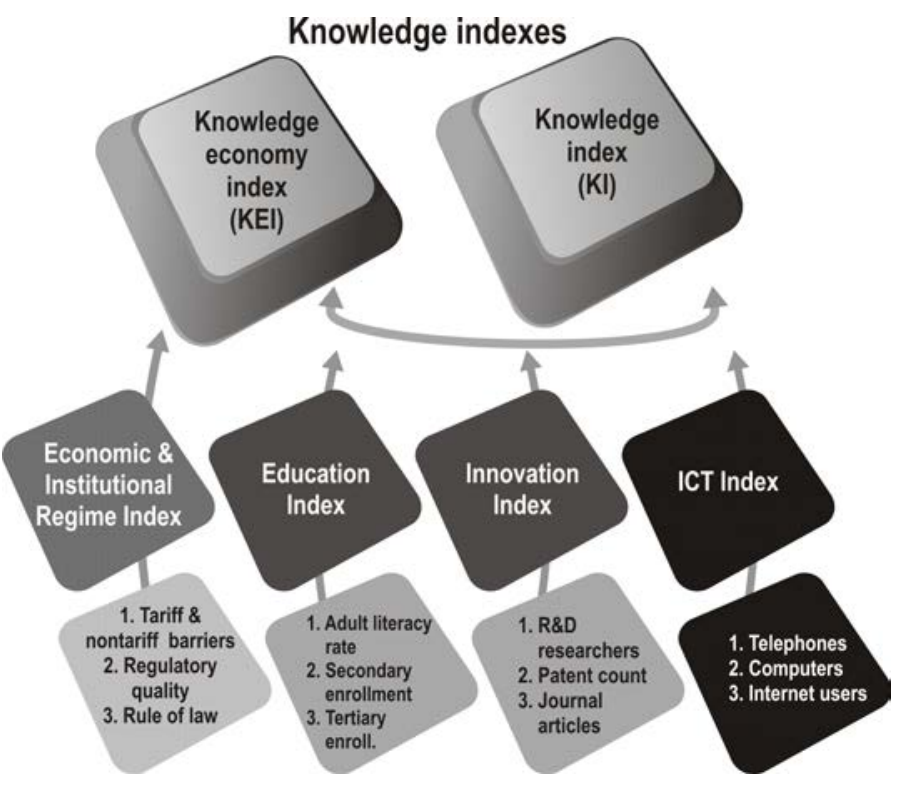

Authors' design modified according to: (World Bank Group, 2012)

KAM methodology gives quick and concise overview of the most significant advantages and disadvantages, as well as overview of fields in which the improvement in development of knowledge-based economy was registered. Knowledge indicators are also used for calculation of total knowledge index and knowledge economy index. 
Nedić V. et al.: ICT as a Component of Knowledge Economy Development of ...

$\mathrm{KEI}$ is the indicator which measures the capability of a country or region to develop economy based on knowledge, that is, to illustrate the suitability of the environment for efficient use of knowledge for economic development. KEI is aggregate index which represents total level of a country's or a region's development in relation to knowledge economy. It is calculated based on the average of normalized performance of a country or region for all 4 pillars related to knowledge economy - economic incentive and institutional system, education and human resources, innovation system and ICT. (Fig. 2)

Economic and institutional regime provides incentives for efficient use of existing and new knowledge and leads to the affirmation of entrepreneurship. Educated and adequately trained population can create, share and use knowledge. Efficient innovation system of the companies, research centers, universities, expert consultants, and other organizations can be incorporated in growing actions of global knowledge, assimilated and adjusted to local needs and they can create new technology. Modern and accessible ICT infrastructure can facilitate communication, dissemination and processing of information (Fig. 3).

Figure 3. The four interactive pillars of knowledge economy

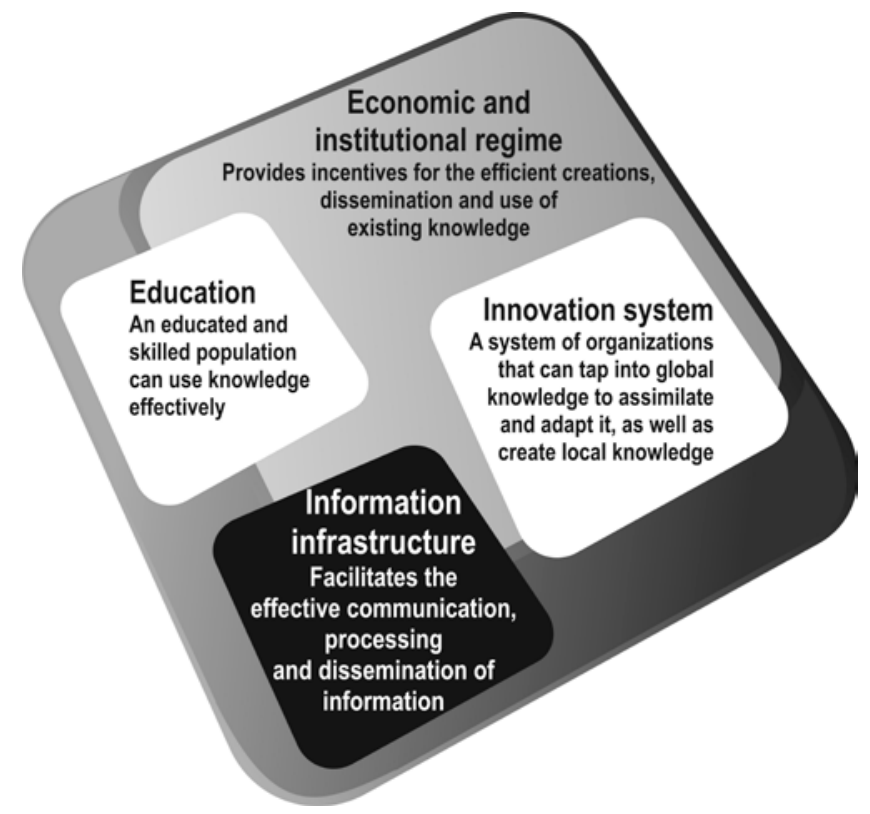

Authors' design modified according to: (World Bank Group, 2010)

$\mathbf{K I}$ is an indicator of the overall potential of knowledge development in given country and it measures country's potential to create, adopt and share the 
Nedić V. et al.: ICT as a Component of Knowledge Economy Development of ...

knowledge. It is calculated as the average of normalized performance of the most significant indicators for the country or the region which comprise three pillars of knowledge economy: education and human resources, innovation system and ICT. Unlike knowledge economy index whose calculation is based on all four pillars of knowledge economy, knowledge index includes three pillars (the first pillar- Economic and Institutional regime is left out).

ICT, as an infrastructural component of knowledge economy, should enable efficient creation, dissemination and processing of information. This component is presented as ICT pillar within KAM which is calculated based on twelve variables, three out of which are considered key variables (Fig. 4).

Figure 4. ICT pillar with key and other variables

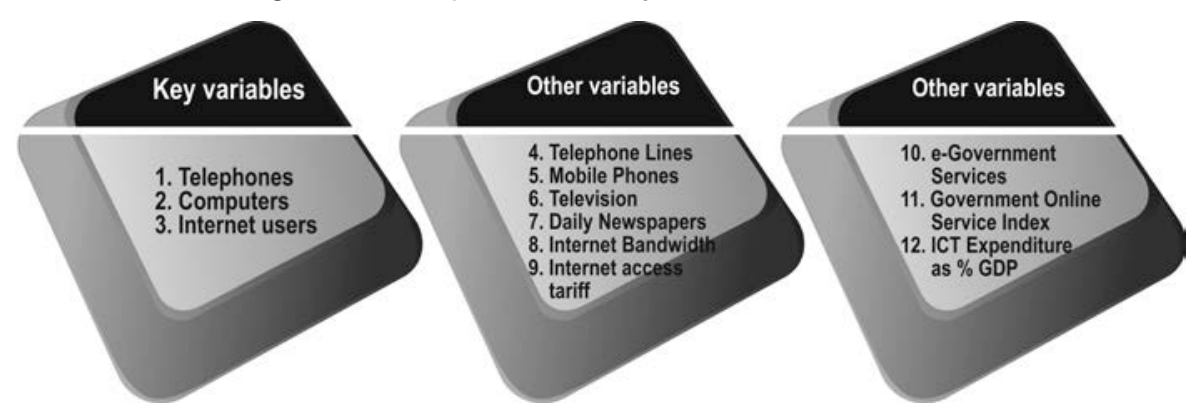

Authors' design modified according to: (World Bank Group, 2010)

Based on the described measurement, using the data from KAM database (World Bank Group, 2014), the paper examined ICT as an infrastructural component of knowledge economy development in four Western Balkan countries. As mentioned, the control group of the empirical research also included six EU neighboring countries. The evaluation of the level of ICT application in observed European countries was presented as an overview of aforementioned twelve variables of ICT pillar by applying KEl:

a) Simple correlation analysis in order to examine the degree of interdependence of ICT pillar, other pillars of knowledge economy, and GDP per capita at:

i. Global level for all 146 countries and

ii. Level of ten analyzed European countries.

b) Cluster analysis which will:

i. Check the level of variation according to ICT parameters,

ii. Perform grouping of observed countries in clusters and

iii. Detect observed countries that show significant deviation when compared to the rest of the group. 
Nedić V. et al.: ICT as a Component of Knowledge Economy Development of ...

c) Radar chart analysis of individual variables of ICT pillar in order to determine the current situation in terms of values of partial indicators of ICT pillar and to enable the overview of comparative position of observed economies,

d) Over time comparisons of the most recent available values of key variables of ICT pillar in comparison to data from 2000 in order to show the development dynamics of ICT in the given period.

All the analyses have been conducted with the use of statistic tools within MS Excel program.

\section{Results and discussion}

Fig. 5 shows diagrams of dispersity with the aim to visualize the intensity of the relation of ICT pillar with other KEI pillars, for 146 countries comprised by KEI Framework. A strong interdependence can be observed between ICT pillar and three other index pillars, the strongest one being with Innovations, followed by Education, while the Economic Regime has the least strong interdependence (the latest data of $\mathrm{KEI}$ ). Analysis included an additional parameter, GDP per capita, (1,000 US\$), as an indicator of achieved level of economic development of certain countries.

Figure 5. Correlation diagrams of ICT pillar (146 countries)
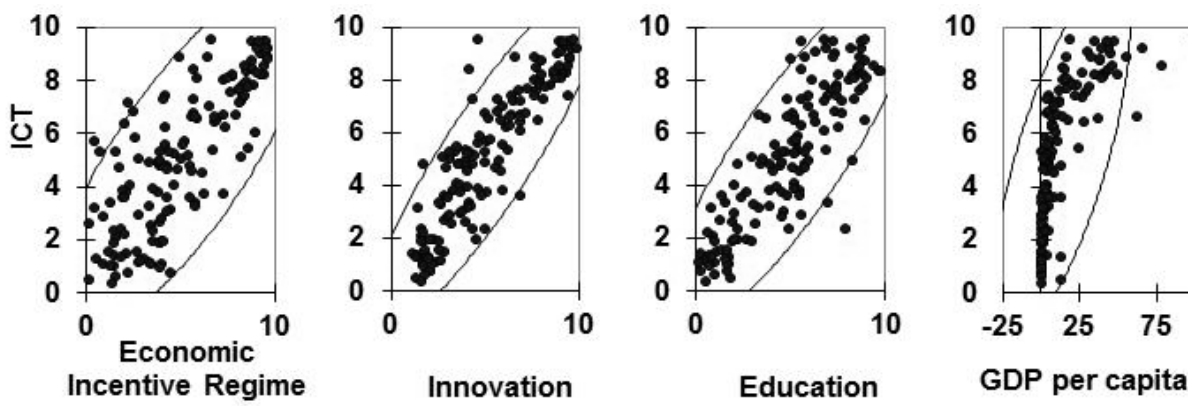

Source: Authors' calculation based on World Bank Group database, 2014

Considering the fact that the visualization detected potential interdependence, further analysis focused on researching the interdependence of the relation by using correlation analysis. Table 1 shows key descriptive statistical indicators of observed variables, while Table 6 , in matrix form, shows correlation coefficients between observed variables. 
Nedić V. et al.: ICT as a Component of Knowledge Economy Development of ...

Table 1. Summary statistics of correlations: (146 countries)

\begin{tabular}{|l|ccccc|}
\hline \multicolumn{1}{|c}{ Variable } & Min & Max & Mean & $\begin{array}{c}\text { Std. } \\
\text { deviation }\end{array}$ & $\begin{array}{c}\text { Coefficient of } \\
\text { variations }\end{array}$ \\
\hline $\begin{array}{l}\text { Economic Incentive } \\
\text { Regime }\end{array}$ & 0.120 & 9.660 & 5.180 & 2.746 & 0.53 \\
Innovation & 1.170 & 9.860 & 5.233 & 2.536 & 0.48 \\
Education & 0.170 & 9.810 & 5.010 & 2.653 & 0.53 \\
ICT & 0.320 & 9.540 & 5.199 & 2.680 & 0.52 \\
GDP per capita & 0.332 & 99.282 & 13.604 & 18.055 & 1.33 \\
\hline
\end{tabular}

Source: Authors' calculation based on World Bank Group database, 2014 Retrieved from http://www.worldbank.org/kam

Table 1 shows that variation coefficients of input data are very high (which points out that with these variables there is a big share of statistical disturbances, which reduces the accuracy of forecast of the model), still this is expected for the data on global level (146 countries). Especially high variation coefficient can be observed with variable GDP per capita, but it also had high value in research on regional level (Camagni et al. 2009)

Figure 6. Correlation matrix (Pearson) (146 countries)

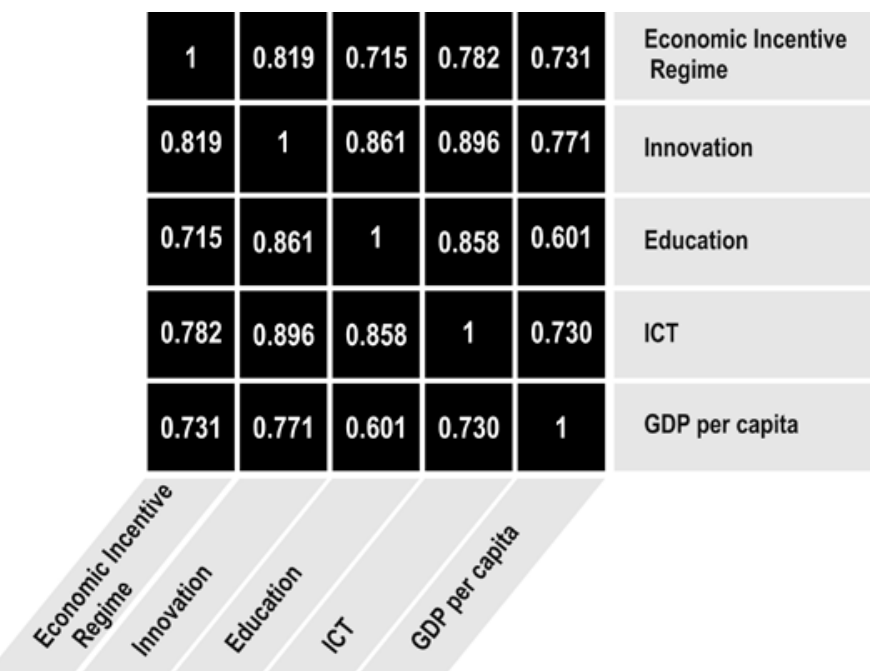

Values in black are different from 0 with a significance level alpha=0.01

Source: Authors' calculation based on World Bank Group database, 2014, Retrieved from http://www.worldbank.org/kam 
Nedić V. et al.: ICT as a Component of Knowledge Economy Development of ...

Correlation matrix according to $\mathrm{R}$ (Fig. 6) gives a numerical evaluation of potential interdependence of analyzed parameters of 146 countries. Values of correlation coefficients point to a strong interdependence, that is to say, it illustrates the existence of high linear correlation between observed variables.

It can be observed that all analyzed correlations have the value $\mathrm{R}$ between 0,7 and 0,9 . Upon testing, it can be concluded that all correlation coefficients are statistically significant, the level of the significance being $1 \%$, which therefore gives them great importance in further consideration.

Since, due to high multicollinearity, multiple regression analysis is not recommended (at least not using linear function), and having in mind that this paper is focused on KAM's ICT pillar, we proceeded our analysis using two dimensional regression model using linear and exponential functions.

Table 2. Description of linear and exponential two dimensional regression model

\begin{tabular}{|l|c|c|}
\hline \multicolumn{1}{|c|}{ Function } & Formula & Variable description \\
\hline Linear function & $\mathrm{Y}=\mathrm{aX}+\mathrm{b}$ & $\mathrm{X}-$ value of KAM's ICT pillar \\
\cline { 1 - 2 } $\begin{array}{l}\text { Exponential } \\
\text { function }\end{array}$ & $\mathrm{Y}=\mathrm{ae}^{\mathrm{X}^{*} \mathrm{~b}}$ & $\mathrm{Y}-\mathrm{GDP}$ per capita (current 1,000US\$) \\
\hline
\end{tabular}

Figure 7. Regression diagram for dependence of GDP pc from ICT value (146 countries)

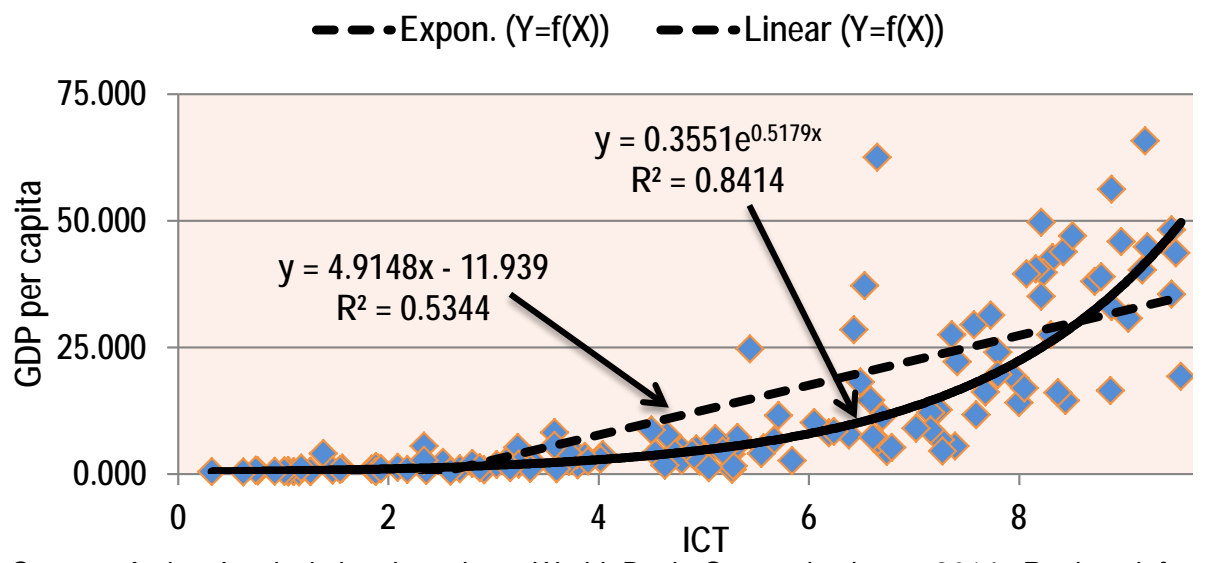

Source: Authors' calculation based on World Bank Group database, 2014, Retrieved from http://www.worldbank.org/kam

Fig. 7 presents a diagram of linear and exponential regression model of ICT influence on GDP per capita, on global level. Using the analysis of the relation of variables mentioned above, the high degree of correlation between linear 
Nedić V. et al.: ICT as a Component of Knowledge Economy Development of ...

and exponential model was determined. Even with high coefficient of exponential model $(R=0,917)$, the significance of dependence was analyzed further with $F$ statistics $(F($ theoretical $)=253<F=731)$ and $\mathrm{H} 1$ hypothesis was confirmed.

It is our opinion that a potential relation of variables ICT and GDP pc evidently exists, though the further research of this relation should include analysis of the series of data concerning variables in a different time frame.

Further analysis of observed variables focuses on ten countries (Western Balkan countries and EU countries in their immediate surrounding)

Table 3 presents key descriptive statistical indicators of observed variables for 10 selected countries while Fig. 8 presents correlation coefficients between observed variables in matrix form.

Table 3: Summary statistics of correlations: (10 countries)

\begin{tabular}{|c|c|c|c|c|c|}
\hline Variable & Min & Max & Mean & Std. deviation & $\begin{array}{c}\text { Coefficient of } \\
\text { variations }\end{array}$ \\
\hline $\begin{array}{l}\text { Economic Incentive } \\
\text { Regime }\end{array}$ & 4.230 & 9.260 & 6.666 & 1.594 & 0.24 \\
\hline Innovation & 3.370 & 8.870 & 6.515 & 1.814 & 0.28 \\
\hline Education & 4.810 & 8.960 & 6.537 & 1.262 & 0.19 \\
\hline$I C T$ & 4.770 & 8.970 & 6.821 & 1.270 & 0.19 \\
\hline GDP per capita & 3.846 & 45.872 & 14.523 & 14.034 & 0.97 \\
\hline
\end{tabular}

Source: Authors' calculation based on World Bank Group database, 2014, Retrieved from http://www.worldbank.org/kam

Table 3 shows that variation coefficients of input data of the region are still statistically high, but much lower than on global level (146 countries). The highest coefficient of variation can still be observed in variable GDP per capita. However it is significantly lower than in the series of global data.

Similarly to the previous matrix, the values of coefficients point to the existence of high linear correlation between the majority of observed variables in countries included by the sample. The only relation which has no statistical significance is detected between ICT pillar and education pillar.

It can be observed that analyzed correlations of ICT pillar ( as key pillar for this paper) and other pillars (except education pillar) have $\mathrm{R}$ value between 0.6 and 0.85 and they are still significant for further consideration ( critical values for given population on the level of significance of $5 \%$ and $10 \%$ are 0.632 and 0.549 respectively). 
Nedić V. et al.: ICT as a Component of Knowledge Economy Development of ...

Figure 8. Correlation matrix (Pearson) (ten analyzed European countries)

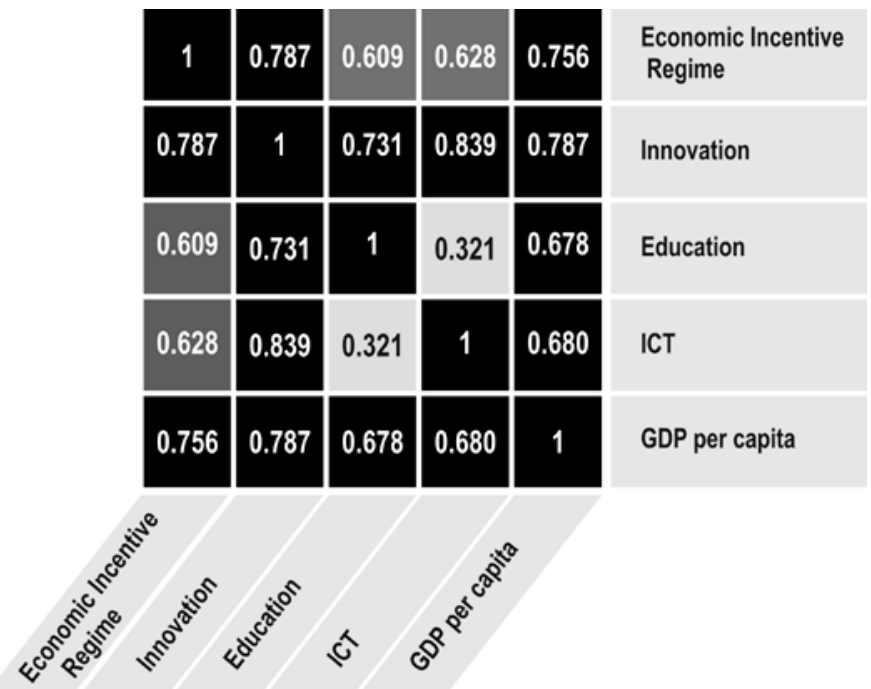

Values in black are different from 0 with a significance level alpha $=0.05$

Values in gray are different from 0 with a significance level alpha $=0.10$

Source: Authors' calculation based on World Bank Group database, 2014, Retrieved from http://www.worldbank.org/kam

Our intention was to point to the existing connection by using correlation analysis, that is, to examine quantitative agreement between variations of observed variables. High level of agreement between ICT and other observed variables, in particular GDP per capita, does not allow us to conclude that the strengthening of ICT will have an automatic impact on the increase of the rate of economic growth. However, having in mind the pervasive character of ICT in all economic activities, and their influence on the change of the structure of national economies, it is possible to suppose that the lagging of certain countries in ICT application, among other things, has a negative effect on dynamics of economic growth as a key macroeconomic performance.

Without plunging any deeper in researching cause-and-effect relationship between observed variables, being that it would demand a deeper analysis and application of additional methods, which goes beyond the scope of this paper, further on, the emphasis of this paper is placed on the overview of ICT application in observed groups of countries, which is the aim of research in this paper.

Fig. 9 shows the clustering of observed ten countries based on the most recent available values of all variables included in ICT pillar of KEI. 
Nedić V. et al.: ICT as a Component of Knowledge Economy Development of ...

Figure 9. Overview of the dendrogram of cluster analysis according to variations - the calculation included all variables of ICT pillar of KAM framework (normalized values $\min =1 ; \max =10$ ) for the selected countries

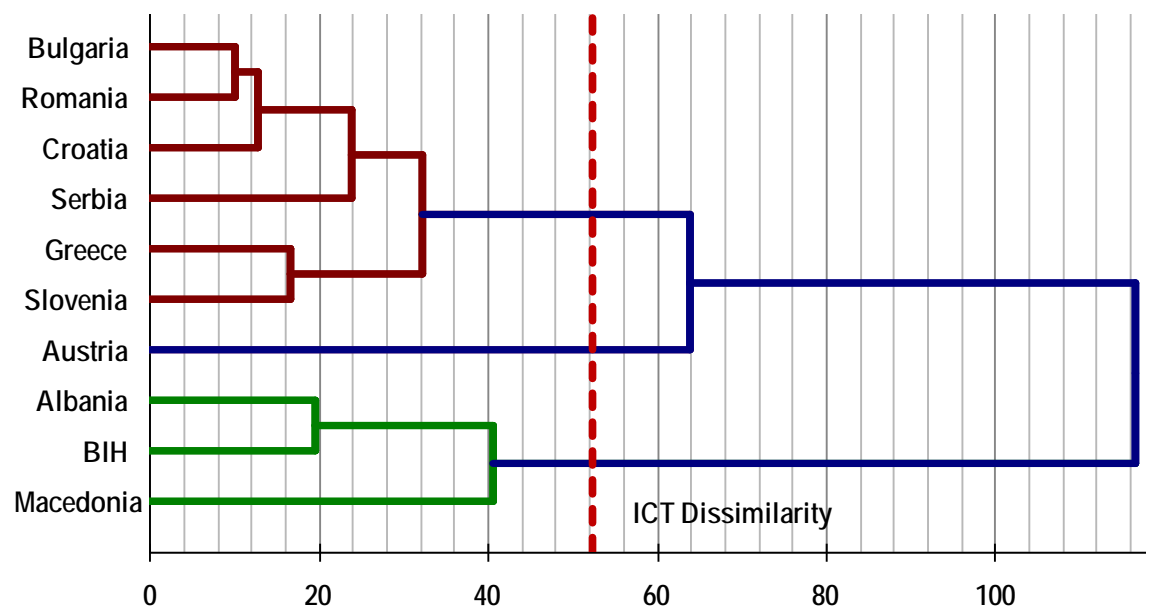

Source: Authors' calculation based on World Bank Group database, 2014, Retrieved from http://www.worldbank.org/kam

During the grouping procedure (clusterization) of 10 selected countries, a bottom-up approach of agglomerative hierarchical clustering was used. Initially each country was treated as a separate cluster. Their grouping, based on similarities in terms of values of observed variables, represents the result of all later iterations of clustering until the observed entities are unified within one cluster. At the variation level of about 40 taken as a possible dendogram limiting value, three clusters of observed countries can clearly be identified. The first cluster includes 6 member countries of observed group, out of which only Serbia is outside of EU, the second cluster is made of 3 member countries of observed group which are outside of EU, and the third cluster includes only one member country of the observed group - Austria.

At the variation level of 65 Austria joins the first cluster. Only at the variation level of 120 does the third cluster join the first and the second cluster. Clustering based on all variables of ICT pillar greatly coincides with the EU membership of observed countries (the only exception is Serbia). On the other hand, there are also significant variations between the countries inside the cluster and they do not decrease until the final level of clustering (each country from the observed group represents its own cluster).

According to our opinion, cluster analysis additionally shows the purpose of selected group of countries, since no member showed extreme deviations. 
Nedić V. et al.: ICT as a Component of Knowledge Economy Development of ...

Following this, we will give a comparative overview of the most recent available data through: a) bar diagram for mean values according to observed groups of countries, where observed variables related to selected groups of countries were determined as average of the results which the countries achieved in the field of ICT and b) radar of diagrams for all observed countries separately. The overview includes variables that comprise ICT pillar. Graphic overview of analyzed variables is given on Figures 10, 11, and 12.

Figure 10. Key variables of ICT pillar of KEI
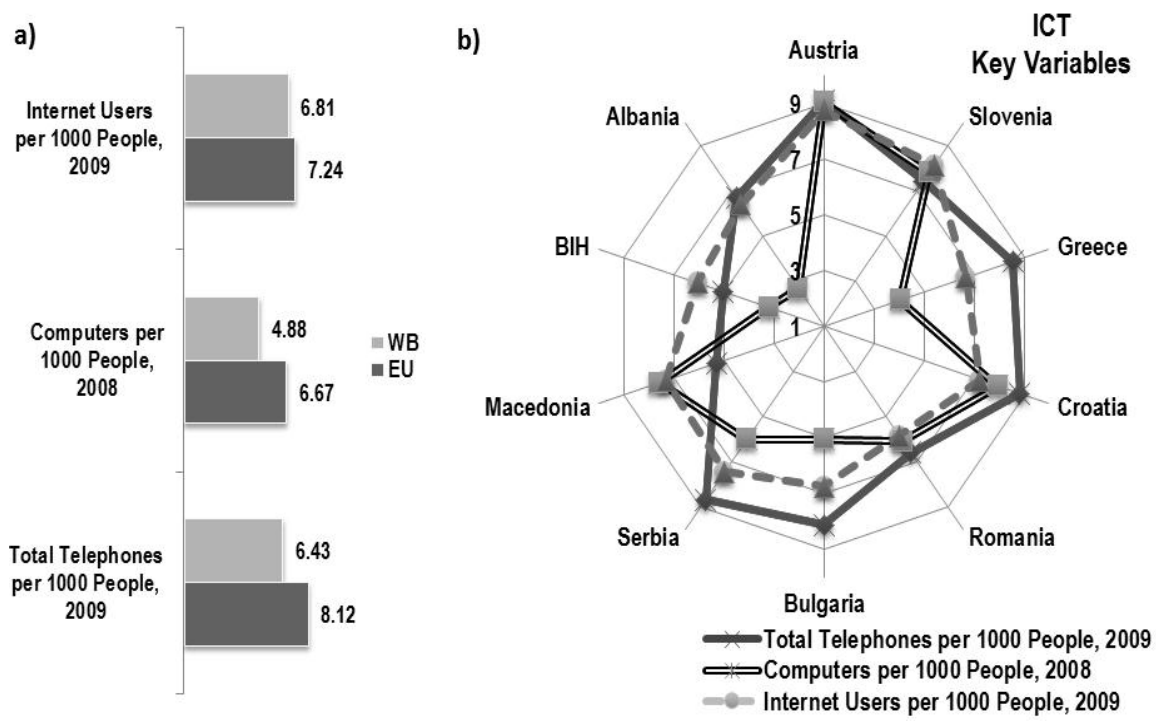

Source: Authors' calculation based on World Bank Group database, 2014, Retrieved from http://www.worldbank.org/kam

Based on the comparison of key variables of ICT pillar for the observed groups of countries it can be observed that:

a) Western Balkan countries lag behind according to all three ICT key variables, especially in variables Computer per 1000 people and Total telephone per Computer per 1000, while variable Internet user per 1000 people shows slightly better results.

b) At individual overview of key variables we can detect:

i) A significant variation of indicators Total telephones (landline and mobile) per 1000 people (from the group of Western Balkan countries only Serbia was in the rank with EU countries) 
Nedić V. et al.: ICT as a Component of Knowledge Economy Development of ...

ii) A very significant variation of indicators Internet Users per 1000 people

iii) A comparatively balanced value of indicator Internet Users per 1000 people

General impression is that BIH, Albania, and partially Greece and Macedonia lag behind the most, while Austria and Slovenia have the most balanced and highest positions.

Figure 11. Other variables of ICT pillar of KEI

a)

a) Daily

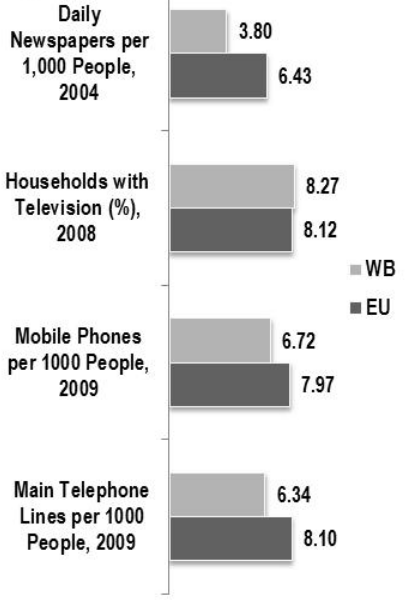

b)

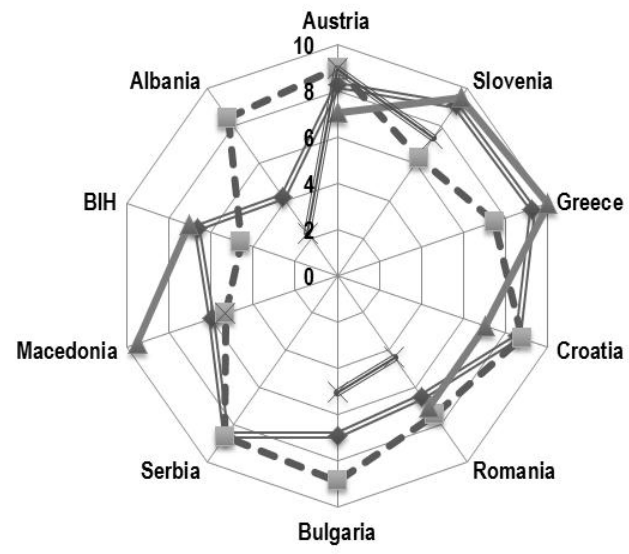

$\square$ Main Telephone Lines per 1000 People, 2009

- Mobile Phones per 1000 People, 2009

-Households with Television (\%), 2008

$\Longrightarrow$ Daily News papers per 1,000 People, 2004

Source: Authors' calculation based on: World Bank Group database, 2014, Retrieved from http://www.worldbank.org/kam

Based on the comparison of other variables of ICT pillar it can be concluded that:

a) Western Balkan Countries show significant lagging behind selected EU countries. The exception was variable Households with television (\%), where there is a slightly growing trend in relation to the average of EU neighboring countries.

b) In the individual overview of the group of indicators shown on Fig. 11b there is a problem with the lack of data in underdeveloped countries of the observed group, and it is also evident that there is a significant lagging of $\mathrm{BIH}$, Albania, Macedonia. 
Nedić V. et al.: ICT as a Component of Knowledge Economy Development of ...

Figure 12. Other variables of ICT pillar of KEI

a)

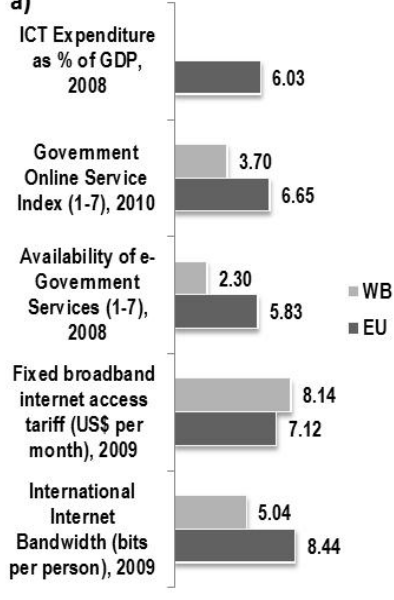

b)

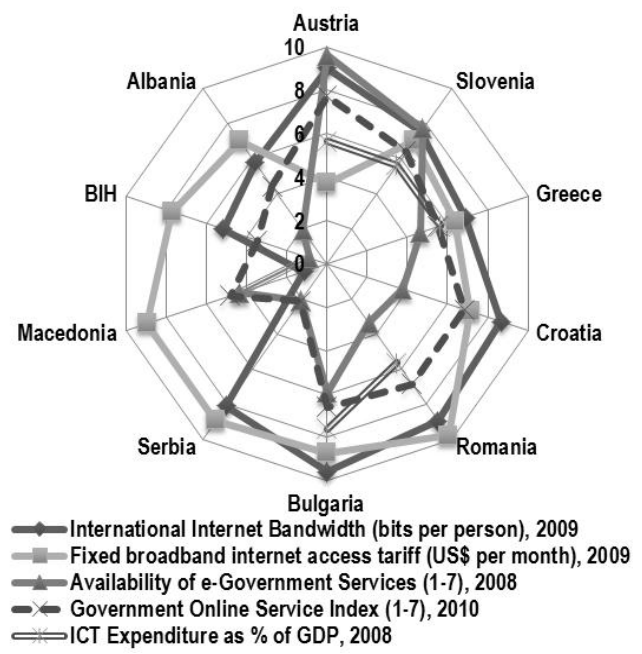

Source: Authors' calculation based on World Bank Group database, 2014, Retrieved from http://www.worldbank.org/kam

Third group of observed indicators (Fig. 12) is linked to strategic and infrastructural indicators, and based on this group it can be concluded that:

a) There is a certain drawback in countries outside of EU when it comes to the accessibility of e-administration services (Government online service), as well as their quality (Availability of e-government service). This drawback is the key problem in Balkan countries in the process of achieving the level of ICT application in EU member countries from their immediate surroundings. This demands defining a long-term strategy for knowledge economy development on both national and regional level.

b) In individual approach when analyzing aforementioned variables in the field of e-administration we have detected an alarming lagging of Serbia and $\mathrm{BIH}$.

Detected gap depth, when reached ICT application level is concerned, between Western Balkan countries and selected EU countries, based on cluster and radar chart analyses, confirms that hypothesis $\mathrm{H} 2$ is true.

Furthermore, the paper gives an overview of ICT pillar data and its key variables which compares the situation from 2000 to the most recent available data on current state and includes all the countries of the observed group, except for Serbia, as there are no available data for this year. 
Nedić V. et al.: ICT as a Component of Knowledge Economy Development of ...

Figure 13. Over time comparison of the most recent available values of ICT pillar and its key variables in relation to the value from 2000.
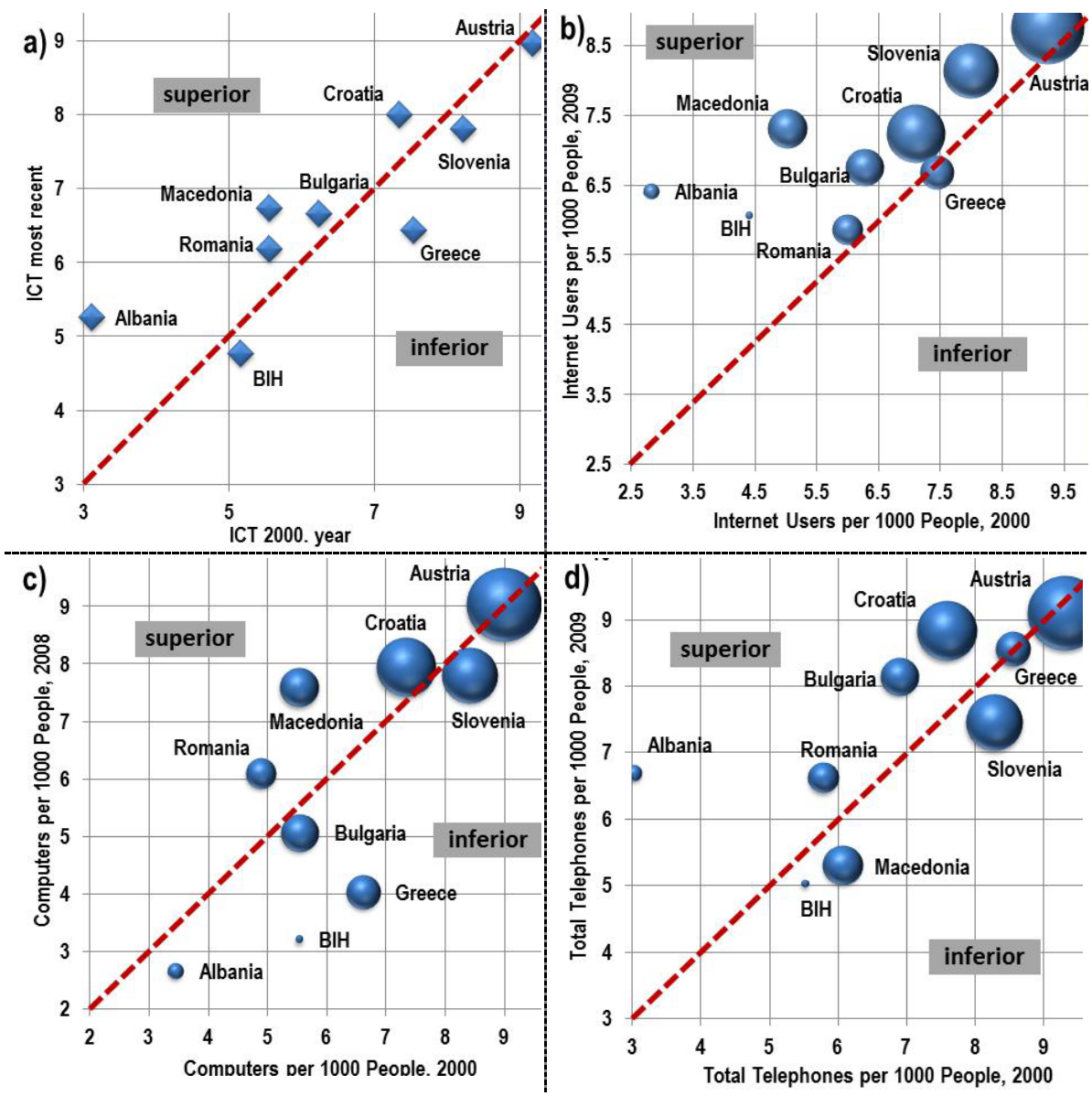

Note: There are no available data for Serbia for 2000. Balloons show a relative relationship of the latest available values of ICT pillar.

Source: Authors' calculation based on World Bank Group database, 2014, Retrieved from http://www.worldbank.org/kam

a) Based on over time comparison of the values of ICT pillar it can be concluded that:

- There is a clearly visible trend of improvement of the rank of less developed countries in Europe, except for BIH,

- Greece and Slovenia, and BIH show great regression, 
Nedić V. et al.: ICT as a Component of Knowledge Economy Development of ...

- Country that does not show significant changes after 2000 is Austria, which is the group leader (in the previous cluster analysis it was grouped into its own subcluster), while there are no available data about the value of this pillar for Serbia in 2000.

b) Based on over time comparison of the most recent available values of variable Internet users per 100 people it is possible to conclude:

- That there is an obvious trend of improvement of observed indicator for all countries, except for Greece.

- That Macedonia and two least developed countries, according to ICT pillar, Albania and BIH have shown a significant progress according to this variable

- Country that has not shown any significant changes since 2000 is Austria, group leader (in the previous cluster analysis it regrouped as its own subcluster), while for Serbia there are no available data about the value of this pillar in 2000. Based on over time comparison of two other key variables of the level of ICT application: c) Computers per 1000 people and d) Telephones per 1000 people, it is possible to conclude that:

- $\quad$ These two key variables do not show a particularly positive trend as the variable Internet users per 1000 people.

- Austria, as the country with the strongest ICT pillar, showed stagnation in both variables which indicates that we should adjust indicators towards the technological progress in this area.

- Most of the countries showed weakened positions in the values of variable Computers per 1000 people except for Romania, Macedonia and Croatia.

- Variable Telephones per 1000 people shows that most countries have progress (BIH, Macedonia and Slovenia showed lagging behind)

\section{Conclusion}

Based on the results of regression analysis at global level (for 146 countries), the paper shows existence of a positive effect of ICT on GDP per capita.

Overview of ICT as an infrastructural component of knowledge economy development in Western Balkan countries (Albania, Montenegro, Macedonia, Serbia) and six countries from their immediate surroundings (Austria, Bulgaria, Greece, Croatia, Romania and Slovenia) has pointed out that Western Balkan countries seriously lag behind selected EU members in terms 
Nedić V. et al.: ICT as a Component of Knowledge Economy Development of ...

of level of ICT application. It is especially troubling that the biggest lagging is recorded in the field of accessibility and quality of e-administration.

We believe that the identified gap in ICT application in Western Balkan countries in comparison to EU countries means a slight going backwards in knowledge economy development and, moreover, in the development of information society as a whole.

Encouraging circumstance is that a certain improvement trend has been detected in the increase of ICT pillar value for all Western Balkan countries based on over time analysis. This positive trend is best seen at the key variable Internet user per 1000 people. On the other hand, the most developed countries of the observed group (Austria and Slovenia) do not see any special changes of ICT indicators and there is another convergence with three key ICT indicators towards unique denominator (radar diagram of ICT key variables). Therefore we believe that a significant adaptation of ICT pillar structure is needed in order to keep up with key technological and social changes in this field. We should take into consideration that this field is growing so rapidly, that indicators defined in this manner lose their sense in the future.

\section{Reference}

Araya, D. (2010). Educational policy in the creative economy. In Education in the creative economy: Knowledge and Learning in the age of innovation. (pp. 328).

Atkinson, R.D., \& Gottlieb, P.D. (2001). The metropolitan new economy index. Progressive Policy Institute and Center for Regional Economic.

Atkinson, R.D. (2007). Boosting European prosperity through the widespread use of ICT. (p. 11). The Information Technology \& Innovation Foundation.

Brinkley, I. (2006). Defining the knowledge economy. (p. 19). London: The work foundation.

Brynjolfsson, E., \& Hitt, L. (1996). Paradox lost?, Firm-level evidence on the returns to information systems spending.Management science, 42(4), 541-558.

Camagni, R., Capello, R., \& Nijkamp, P. (2009). Territorial capital and regional development. In Handbook of Regional Growth and Development Theories. (pp. 118-132).

Carayannis, E.G., Popescu, D., Sipp, C., \& Stewart, M. (2006). Technological learning for entrepreneurial development (TL4ED) in the knowledge economy (KE): case studies and lessons learned. Technovation, 26(4), 419-443.

Colecchia, A., \& Schreyer, P. (2002). ICT investment and economic growth in the 1990s: is the United States a unique case?: a comparative study of nine OECD countries. Review of Economic Dynamics, 5(2), 408-442.

Despotovic, D. Z., Cvetanović, S. Ž., \& Nedić, V. M. (2014). Innovativeness and Competitiveness of the Western Balkan Countries and Selected EU Member States. Industrija, 42(1) 
Nedić V. et al.: ICT as a Component of Knowledge Economy Development of ...

Drašković, M. (2010). Znanje kao neograničen resurs i objekt upravljanja. Montenegrin Journal of Economics, 11, 83-90.

Drašković, V. Jovović, R. Drašković, M. (2013). Fenomenološki i paradigmatični elementi ekonomije znanja. Ekonomske ideje i praksa, br. 8. str. 7-24.

Trewin, D. (2002). Measuring a Knowledge-based Economy and Society: An Australian Framework. Australian Bureau of Statistics.

Landefeld, J.S., \& Fraumeni, B.M. (2001). Measuring the new economy. Survey of Current Business, 81(3), 23-40.

Lojpur, A.S. (2013). Znanje i inovaciona politika zemalja u tranziciji kao mjera spremnosti za ulazak u EU. (p. 61). ELIT-Economic Laboratory for Transition Research.

Krstić, B., \& Džunić, M. (2013). Knowledge economy and competitiveness of western Balkan countries in the global economic crisis. Teme, 37(1), 141-162.

Mandel, M.J. (1997). The new business cycle. Business Week, 31, 58-68.

Mann, C. L., \& Rosen, D. H. (2002). New Economy and APEC, The. Peterson Institute Press: All Books.

Negroponte, N. (1996). Being digital. Random House LLC..

Ollo-López, A., \& Aramendía-Muneta, M.E. (2012). ICT impact on competitiveness, innovation and environment. Telematics and Informatics, 29(2), 204-210.

Pilat, D. (2005). The economic impacts of ICT-Lessons learned and new challenges. In: Eurostat Conference "Knowledge Economy-Challenges for Measurement.

Rai, L.P., \& Lal, K. (2000). Indicators of the information revolution. Technology in Society, 22(2), 221-235.

Selhofer, H., Lilischkis, S., Alkas, H., \& O'Donnell, P. (2010). ICT and e-Business for an Innovative and Sustainable Economy. 7th Synthesis Report of the Sectoral e-Business Watch. Luxembourg: Office for Official Publications of the European Communities.

Shapiro, C., \& Varian, H.R. (2013). Information rules: A strategic guide to the network economy. Harvard Business Press.

Škuflić, L., \& Vlahinić-Dizdarević, N. (2003). Koncept nove ekonomije i značaj informacijsko-komunikacijske tehnologije u Republici Hrvatskoj. Ekonomski pregled, 54(5-6), 460-479.

-World Bank Group. (2010). Measuring Knowledge in the World's Economies. Retrieved from http://siteresources.worldbank.org/INTUNIKAM/Resources/KAMbooklet.pdf

-World Bank Group. (2012). Knowledge Economy Index (KEI) 2012 Rankings. Retrieved from http://siteresources.worldbank.org/INTUNIKAM/Resources/2012.pdf

-World Bank Group. (2014). Knowledge Assessment Methodology 2012 - Database. Retrieved from http://www.worldbank.org/kam 